\title{
The Large Mammals in Arabia
}

\author{
By David L. Harrison
}

In this brief review of the status and conservation needs of the larger mammals of the Arabian peninsula, Dr Harrison, author of the standard work on the subject (volume 2 will be reviewed in the next ORYX) finds the situation not entirely depressing. Arabian oryx still probably number several hundred. The species that are in some danger include genet, lynx, leopard, cheetah, tahr, goat, red sheep, dorcas gazelle, Persian fallow deer and roe deer.

THE Arabian peninsula is a country of difficult terrain and a harsh climate. Much remains obscure about the larger mammals, while the disturbed and unstable political conditions make both effective conservation and the acquisition of information very difficult. However, the picture emerging is not so depressing as might be expected.

Sacred baboon Papio hamadryas: the only wild Arabian primate, this baboon is found in the mountains of SW Arabia from south of Jedda through Asir and Yemen and the Aden area east of the Hadhramaut, as far as Wadi Masila (Harrison, 1964). Although very unpopular because of its crop-raiding habits, it still appears to be plentiful in some areas thanks to its inaccessible refuges in precipitous mountain slopes.

Wolf Canis lupus: still widespread in small numbers in the Peninsula, except in the interior of the great desert, though every man's hand is against it. Usually solitary or hunting in pairs. In Arabia the need is still to conserve sheep, not wolves.

Asiatic jackal Canis aureus: once swarming in incredible numbers in Palestine (Tristram 1866), the jackal is still quite numerous in Iraq, Syria, Israel and Jordan, and ranges south to the Oasis of Hofuf in Saudi Arabia, also occurring, although rarely, in SW Arabia. In the southern peninsula its distribution is little known, but it apparently does not exist in Oman.

Red fox Vulpes vulpes: the most abundant predator, occurring everywhere except in the interior of the great deserts.

Ruppell's sand fox Vulpes ruppelli: often mistaken for the fennec, this attractive desert fox is found in the deserts of Sinai, Negev, Nafud and Rub'al Khali, extending north to the Euphrates in Iraq (Hatt, 1959).

Fennec Fennecus zerda: this tiny fox is evidently very rare in Arabia. A single specimen from Kuwait Desert is in the British Museum, and Flower (1932) knew of two from N Sinai. Many references to it in the literature are based on $V$. ruppelli.

Brown Bear Ursus arctos syriacus: probably now extinct in most of its former range in the peninsula, this pale race is in urgent need of protection somewhere in the Middle East if it is not to disappear altogether. It is still found in diminishing numbers in the mountains of north and northeast Iraq (Hatt, 1959). Formerly found in the mountains of Lebanon 


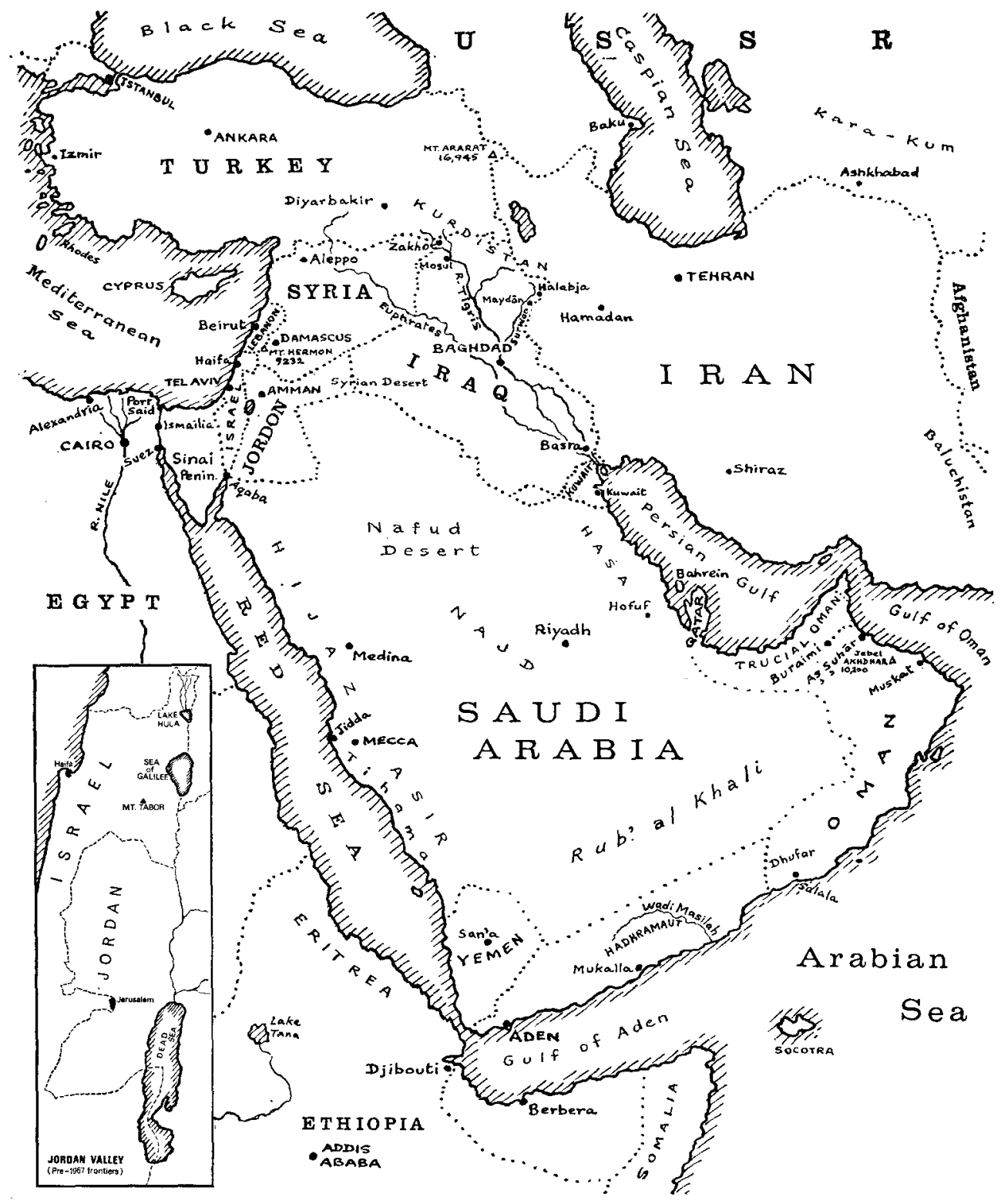


Anti-Lebanon and Hermon in Syria, where Carruthers (1909) obtained one of the last in 1904, it still existed in Israel towards the end of the last century, where Canon Tristram (1888) encountered it near Galilee and said that it occurred then in Jordan to the east. It is interesting that Talbot (1960) suggests the species may still exist in northern Syria and is even still reported from the slopes of Mt. Hermon.

Stone marten Martes foina syriaca: although hunted for its valuable fur, this pale race still exists in small numbers in the wooded parts of Israel, Jordan, Lebanon, Syria and Iraq. It will require some protection, although its increasing scarcity is probably largely due to contraction of habitat.

Marbled polecat Vormela peregusna syriaca: although seldom seen, being shy and largely nocturnal, this beautiful mustelid is apparently not rare in N Iraq, Syria, Lebanon, Israel and Jordan.

Weasel Mustela nivalis: very rare and perhaps a relict species. Tristram (1888) saw it near Mount Tabor in Israel; it was never seen again until D. Potter obtained one in Lebanon in 1951 (Harrison and Lewis, 1964).

Badger Meles meles: abundant along the Mediterranean hills of Israel and Lebanon and occurs in N Jordan, Syria and Iraq.

Ratel or Honey Badger Mellivora capensis: scarce but widespread, this tough, adaptable mustelid ranges far into the deserts, south to Aden and Hadhramaut and east to Dhofar in Oman. It will need a measure of protection in time.

Common otter Lutra lutra: quite numerous along the rivers and in the marshes of S Iraq. In Israel it may have increased in recent years, due to the development of fishponds for carp rearing (Bodenheimer, 1958); found along the Jordan it enjoys a sanctuary in the Lake Huleh Nature Reserve.

Smooth-coated Indian otter Lutra perspicillata maxwelli: known only from the marshes of S Iraq, where it was discovered by Gavin Maxwell (Hayman 1966). As the drainage of these marshes will undoubtedly continue over the years, this interesting otter should be closely watched. A reserve could well be planned in this unique area, which teems with waterbirds.

Small Indian Mongoose Herpestes auropunctatus: extremely common along the rivers of Iraq.

Ichneumon Herpestes ichneumon: quite widespread and abundant in Israel and extending into Jordan, it occurs in Lebanon and probably in Syria, since it extends north to southern Asia Minor.

Indian grey mongoose Herpestes edwardsi: occurs locally on the shores of the Persian Gulf, in Saudi Arabia and Kuwait and presumably in S Iraq.

White-tailed mongoose Ichneumia albicauda: first recorded by Thomas (1894) in Oman, in the vicinity of Muscat, a recent specimen from Sohar and other records provided by Major C. Seton-Browne show that this African, nocturnal mongoose is still abundant on the Batina Coast of 
Oman. It may occur in the Aden area (Thomas 1895) but confirmation is still lacking.

European genet Genetta genetta: very rare. One race occurs in the hills of Israel and near the Dead Sea, another in the mountains north of Aden and in Yemen. It will require conservation.

Striped hyaena Hyeana hyaena: this large scavenger is relatively abundant throughout the peninsula except in the interior of the desert.

Wild cat Felis silvestris: shy and largely nocturnal, it is probably more numerous and widespread than the present limited data suggest; it occurs in Iraq, Syria, Lebanon, Israel and Jordan, south to Kuwait, Sinai, western Saudi Arabia and Aden. This cunning creature will take care of itself. A new race has recently been discovered in Oman (Harrison, 1968).

Sand cat Felis margarita: this unique denizen of true sand desert is known only from a few occurrences in and near Rub'al Khali, but it is probably not so rare as the limited data suggest.

Jungle cat Felis chaus: this handsome diurnal cat is surprisingly abundant in the reed jungles and thickets along the rivers of Iraq, and is also found in a similar habitat in the Jordan Valley. Despite its unpopularity with the Arabs because it preys upon poultry it does not appear to be in danger, although contraction of its habitat will no doubt continue.

Caracal lynx Caracal caracal schmitzi: a scarce secretive inhabitant of steppe and mountain terrain, without doubt more widespread than present limited data suggest, it has occurred in Iraq, Kuwait and Syria, and is apparently not uncommon in the Dead Sea region of Jordan and Israel; the London Zoo has a fine specimen presented by HM King Hussein. Scattered records show that it exists in Sinai, Saudi Arabia and Aden, while a recent specimen from Tawi Suwaihan, near Buraimi shows that it ranges to Oman. I am much indebted to Sheikh Zaid bin Sultan and to Col F. M. de Butts for this specimen.

European lynx Lynx lynx dinniki: there is grave concern for the future of this fine predator in Arabia, where its habitat is much contracted due to deforestation. It probably formerly occurred in Palestine, where Tristram (1888) saw skins, but it now survives only as a rarity in the mountains of north Iraq.

Leopard Panthera pardus: considering the damage done by this dangerous predator it is surprising that it still exists in small numbers throughout the mountainous western, southern, and south-eastern regions of the peninsula; recent occurrences, even in more populated areas such as Israel, are surprisingly frequent. No fewer than four subspecies exist in the peninsula. Although not in immediate danger of extinction, it is hunted remorselessly and the position needs to be carefully watched.

Asiatic cheetah Acinonyx jubatus venaticus: this is one of the most urgent conservation problems, perhaps already too late. An inhabitant of open desert and steppe, it was last definitely reported in 1950 in N Saudi Arabia (Morrison-Scott, 1951) and may yet exist in the remote desert 
tracts where the frontiers of Jordan, Iraq and Saudi Arabia meet. It formerly occurred in Iraq, Syria, Kuwait, Jordan and Sinai. Bedu reports of 'fahad' continue to be received, but unfortunately little reliance can be placed on them; the Arabs are shamelessly inaccurate in the use of popular names.

Hyrax Procavia capensis: this unique little archaic ungulate ranges widely in the mountains and hills of the whole western peninsula, to Lebanon in the north, and central Saudi Arabia and Dhofar in the east. Although it has become scarce in some areas, such as Sinai, it is still locally abundant in Israel and Lebanon, and there is no immediate concern for its future. It enjoys some measure of protection in Israel, and the position will need to be watched elsewhere.

Arabian tahr Hemitragus jayakari: this fascinating goat is one of the few uniquely Arabian mammals. It still exists in fair numbers in the Jebel Akhdar range and its offshoots in Oman. Owing to its restricted habitat and the arrival of oil companies in Oman, which it is feared will inevitably increase hunting pressure, its protection will become increasingly urgent.

Nubian ibex Capra ibex nubiana: another species for which there is concern. Formerly ranging widely in the mountains of Syria, Lebanon, Israel, Jordan, Sinai, Saudi Arabia, Yemen, Aden, Hadhramaut and east to south-west Oman, numbers have greatly diminished in the last half century and, although it is difficult to say whether it has vanished altogether from any part of this range, except perhaps Lebanon, it is certainly only at all numerous today in Hadhramaut and Dhofar. Fortunately it has some protection in Israel; other countries should take urgent steps to safeguard their stocks.

Wild goat Capra aegagrus: greatly reduced by hunting in the mountain ranges of Kurdistan in $\mathbf{N}$ Iraq, this goat will certainly disappear unless protected. The area has been disturbed for some years and the current position is uncertain. The species has just recently been discovered in the Western Hajr of Oman (Harrison, 1967). It will without doubt need conservation in the region.

Red sheep Ovis ammon gmelini: occurs in the mountains of Kurdistan in $\mathbf{N}$ Iraq, where little is known about its status and numbers, and is quite widely distributed in Asia Minor and Iran. It will certainly require conservation measures in time.

Arabian oryx Oryx leucoryx: the story of the rapid disappearance of this elegant antelope from most of its former range in the peninsula during the last half century is very familiar to the Fauna Preservation Society. The history of its decline has been told in detail by Stewart (1963) in his classic study of the species, and the measures taken by the FPS to save it from extinction are well known and will always find a proud place in the history of conservation. It is pleasant to be able to record that the position of the species in the wild is not so grave as had been formerly believed, and probably several hundreds still survive in the south-eastern regions 
of Rub'al Khali. In captivity, too, the position is encouraging. Thanks to Operation Oryx there is a fine herd at Phoenix Zoo, Arizona, and HH Sheikh Qasim bin Hamed al Thani of Qatar has a flourishing breeding herd, a photograph of which was published in ORYX, September 1967.

Goitred gazelle Gazella subgutturosa, Mountain gazelle G. gazella and Dorcas gazelle $G$. dorcas saudiya. A revision of the Arabian gazelles, undertaken by Dr C. Groves and the author, suggests that these three species occur in the peninsula, all in grave danger of extinction due to excessive hunting, especially motorised hunting by organised parties. The position is least serious with $G$. gazella, which inhabits in part mountainous and broken terrain where such methods are impossible. Nevertheless it has become very scarce in much of its range and is now only abundant in the south-east, in Dhofar and Oman proper, where the Sultan has decreed some measure of protection. G. subgutturosa is probably only at all abundant in the sand deserts, which are largely inaccessible to vehicles. The position of the dorcas gazelle G.d. saudiya is the most grave, since it is an inhabitant of the open gravel plains to the east of the Hejaz range, which are exceedingly vulnerable to mechanised hunting. As a result the population in the north of the peninsula has been decimated (Lewis, Lewis and Harrison, 1965). It is possible that a reasonable population still exists in the remote desert tracts in the south-west, between the Yemen and Rub'al Khali.

Wild boar Sus scrofa: still extremely numerous in the marshes of S Iraq and locally along the rivers, and still occurs locally in Syria, Jordan and Israel. Numbers are much diminished but it is certainly not in danger. Its future status is likely to depend upon the continuance of suitable habitat, it will be adversely affected by marsh drainage and clearance of scrubland and reed jungles.

Persian fallow deer Dama dama mesopotamica: threatened with imminent extinction. partly due to hunting pressure and perhaps even more as a result of habitat contraction, this deer may already be extinct in Iraq and Kurdistan. A male was obtained at Zakho in 1917. Field (1955) reported one seen on Jebel Baradust. Hatt (1959) quoted reports received by Lee M. Talbot of survivors in a remote valley between Maidan and Halabja, near the Persian frontier, a place shunned by man because of malarial swamps along the Sirwan River. The area has been disturbed for some years as a result of the Kurdish Revolt and no fresh information is available. The relict population in SW Iran seems the most favourable place to seek a survival captive stock and it may yet not be too late to save the form.

Roe deer Capreolus capreolus: also occurring in the mountains of Kurdistan, this deer is certainly scarce and there is little recent information concerning its status. It has disappeared from its former haunts in Israel and Lebanon and perhaps also in Syria, but is quite widely distributed in Asia Minor and Iran. If it is to survive in the region at all, urgent conservation and habitat preservation are required. 


\section{REFERENCES}

BODENHEIMER, F. S., 1958. The present taxonomic status of the terrestrial mammals of Palestine. Bull. Res. Council Israel. Zool. 7B. 165.

CARRUTHERS, D., 1909 Big game of Syria, Palestine and Sinai. Field, London 114:1135.

FIELD, H. 1955. Animals of Jebel Baradost, Iraq. Amer. Doc. Inst., Doc. No. 4427:60

FLOWER, S. S., 1932 Notes on the recent mammals of Egypt, with a list of the species recorded from that Kingdom. P.Z.S. (London) 1932:369.

HARRISON, D. L., 1964 The mammals of Arabia. Vol. I. p.187. London.

HARRISON, D. L., 1967 Observations on a wild goat, Capra aegagrus (Artiodactyla : Bovidae) from Oman, E. Arabia. J. Zool. (London) $1967: 151 ; 27-30$.

HARRISON, D. L., 1968 The mammals of Arabia, Vol. II. p.195-381. London.

HARRISON, D. L. and LEWIS, R. E. 1964 A note on the occurrence of the weasel, (Mustela nivalis Linnaeus, 1766) (Carnivora : Mustelinae), in Lebanon. Zeit. Säuget. 29(1964) H. 3 : 179.

HATT, R. T., 1959 The Mammals of Iraq. Misc. Pub. Mus. Zool. Univ. Michigan No. $106 ; 40$.

HAYMAN, R. W., 1956 A new race of the Indian smooth-coated otter from Iraq. Ann. Mag. Nat. Hist. Ser. $12: 9 ; 710$.

LEWIS, R. E., LEWIS, J. H. AND HARRISON, D. L., 1965 On a collection of mammals from northern Saudi Arabia. P.Z.S. (London) $1965: 65$.

MORRISON-SCOTT, T. C. S., 1951 Exhibition of photographs of skin of Arabian cheetah. Abstr. Zool. Soc. London, 1951, $1: 2$.

STEWART, D. R. M., 1963 The Arabian oryx (Oryx leucoryx Pallas) East Afr. Wildlife J. $1: 1$.

TALBOT, L. M., 1960 A look at threatened species. A report on some animals of the Middle East and southern Asia which are threatened with extermination. Oryx $5: 153$.

THOMAS, O. 1894 On some specimens of mammals from Oman, SE Arabia. P.Z.S. (London) $1894: 450$.

TRISTRAM, H. B., 1866 Report on the mammals of Palestine. P.Z.S. (London) $1866: 84$.

TRISTRAM, H. B., 1888 The Survey of Western Palestine : Fauna and Flora of Palestine. London. Mammals 1-30.

YERBURY, J. W. and THOMAS, O., 1895 On the mammals of Aden. P.Z.S. (London) 1895, 542-555. 